\title{
Emulsifying Properties of Peptides Obtained from the Hydrolyzates of $\beta$-Casein
}

\author{
Soo Won Lee, Makoto Shimizu, Shuichi Kaminogawa \\ and Kunio Yamauchi \\ Department of Agricultural Chemistry, The Universtiy of Tokyo, \\ Bunkyo-ku, Tokyo 113, Japan
}

Received July 9, 1986

\begin{abstract}
A hydrophobic peptide of 17 residues, $\beta$-CN (f193 209), and a hydrophilic peptide of 25 residues, $\beta-\mathrm{CN}$ ( $\mathrm{f} 1 \sim 25$ ), were isolated from enzyme hydrolyzates of bovine $\beta$-casein. The emulsifying activity (EA) of both peptides was low at a neutral $\mathrm{pH}$. In the acidic or alkaline condition, however, $\beta$-CN (f193 209) showed high EA values. $\beta$ - $\mathrm{CN}(\mathrm{f1} \sim 25)$ also showed high EA values at acidic pHs. These peptides are shown to be more surface active at pH 3 than at $\mathrm{pH} 7$.
\end{abstract}

In the preceding papers, ${ }^{1,2)}$ we reported on the emulsifying properties of an $\mathrm{N}$-terminal $1 \sim 23$ peptide of $\alpha_{\mathrm{s} 1}$-casein. This peptide, $\alpha_{\mathrm{s} 1}{ }^{-}$ $\mathrm{CN}$ (f1 23), showed some unique emulsifying properties: remarkable $\mathrm{pH}$-dependence, concentration-dependence, and a synergistic effect with other peptides. However, more information on the emulsifying properties of many other peptides is required to understand the characteristics of the peptide as an emulsifier.

Bovine $\beta$-casein, whose primary structure has been well established, ${ }^{3,4)}$ has distinctive amphipathic structure in the molecule. Its $\mathrm{N}$ terminal region is hydrophilic, while the $\mathrm{C}$ terminal region is hydrophobic. $\beta$-casein is, therefore, considered to be a good source to prepare peptides of differing hydrophobicity.

In the present study, we isolated two peptides, one hydrophilic and the other hydrophobic, from the hydrolyzates of $\beta$-casein and investigated their properties, especially for emulsification.

\section{MATERIALS AND METHODS}

Preparation of $\beta$-casein. Crude $\beta$-casein was prepared from fresh raw skin milk according to the method of Fox and Guiney. ${ }^{5)}$ This $\beta$-casein was purified on a DEAE-
Sephacel column $(\phi 3.5 \times 20 \mathrm{~cm})$. The elution of $\beta$-casein from the column was carried out with $0.025 \mathrm{M}$ imidazole$\mathrm{HCl}$ buffer $(\mathrm{pH} 6.5)$ containing $4 \mathrm{M}$ urea under a linear gradient of $\mathrm{NaCl}(0 \sim 0.4 \mathrm{M})$.

\section{Preparation of peptides from $\beta$-casein.}

i) $\beta$-CN (f193 209). A $2 \%$ solution of $\beta$-casein in $0.01 \mathrm{M}$ imidazole- $\mathrm{HCl}$ buffer ( $\mathrm{pH}$ 6.5) was incubated with chymo$\sin (\mathrm{Difco})$ at $10^{\circ} \mathrm{C}$ for $3 \mathrm{hr}(\mathrm{E} / \mathrm{S}$ ratio, $1: 50, \mathrm{w} / \mathrm{w})$ and then heated for $5 \mathrm{~min}$ at $80^{\circ} \mathrm{C}$ to inactivate the enzyme. The solution was acidified to $\mathrm{pH} 4.6$ with $0.1 \mathrm{~N} \mathrm{HCl}$ and then centrifuged at $1,840 \times g$ for $10 \mathrm{~min}$. The supernatant was adjusted to $\mathrm{pH} 6.5$ and applied to a DEAE-Sephacel column $(\phi 2.6 \times 20 \mathrm{~cm})$ equilibrated with $0.01 \mathrm{M}$ imidazole$\mathrm{HCl}$ buffer (pH 6.5). $\beta$-CN (f193 209) was eluted by the buffer without retardation. The peptide fraction was repeatedly diluted and concentrated on a G-01T membrane filter (ULVAC Service Corp.) at $4{ }^{\circ} \mathrm{C}$ until free from salts. The solution was then freeze-dried.

ii) $\beta$ - $\mathrm{CN}(\mathrm{f} 1 \sim 25)$. The $\beta$ - $\mathrm{CN}(\mathrm{f} 1 \sim 25)$ peptide was isolated according to the procedure of Peterson et. al. ${ }^{6)}$ with slight modification. A $2 \%$ solution of $\beta$-casein in $0.1 \mathrm{~m}$ ammonia-formic buffer ( $\mathrm{pH} 8.05$ ) was incubated with trypsin (trypsin-TPCK, Worthington) at $20^{\circ} \mathrm{C}$ for $10 \mathrm{hr}$ (E/S ratio, $1: 5000, \mathrm{w} / \mathrm{w})$. The solution adjusted to $\mathrm{pH} 4.7$ was centrifuged at $1,840 \times g$ for $10 \mathrm{~min}$. The clear supernatant was then made $0.25 \%$ with respect to $\mathrm{BaCl}_{2}$ by the addition of a $10 \% \mathrm{BaCl}_{2}$ stock solution, before an equal volume of absolute ethanol was added. The crude barium phosphopeptide was precipitated by centrifugation and dried with acetone and ether. It was further purified by adjusting the $\mathrm{pH}$ to $3.5 \rightarrow 2.0 \rightarrow 3.5$. The precipitate at $\mathrm{pH}$ 3.5 was resolubilized in $0.025 \mathrm{M}$ imidazole- $\mathrm{HCl}$ buffer ( $\mathrm{pH}$ 6.5) containing ethylenediaminetetraacetic acid (EDTA). 
The solution was adjusted to $\mathrm{pH} 6.5$ and fractionated on a DEAE-Sephacel column $(\phi 2.1 \times 18 \mathrm{~cm})$ with $0.025 \mathrm{M}$ imidazole- $\mathrm{HCl}$ buffer $(\mathrm{pH}$ 6.5) under a linear gradient of $\mathrm{NaCl}(0 \sim 0.6 \mathrm{M})$. The peptide fraction was desalted by passage through Sephadex G-15 (Pharmacia Fine Chemicals Co.) and then freeze-dried.

High-performance liquid chromatography (HPLC). A high-performance liquid chromatograph (Jasco Trirotor SR-2) was fitted with a Lichrosorb RP-18 column $(\phi 4.0 \times 250 \mathrm{~mm}$, Merck $)$ and a UV detector at a wavelength of $230 \mathrm{~nm}$. The sample was eluted with $0.1 \%$ trifluoroacetic acid (TFA)-acetonitrile as a mobile phase at a flow rate of $1 \mathrm{ml} / \mathrm{min}$. The concentration of the mobile phase modifier (acetonitrile) was increased linearly from $0 \sim 95 \%$ over $60 \mathrm{~min}(1.58 \% / \mathrm{min})$.

Amino acid analysis. A peptide separated on HPLC was evaporated to remove the TFA and acetonitrile, and was then dissolved in $6 \mathrm{~N} \mathrm{HCl}$. The solution was degassed and hydrolyzed at $110^{\circ} \mathrm{C}$ for $24 \mathrm{hr}$. The hydrolyzate was analyzed with an automatic amino acid analyzer (Hitachi Model 835).

Emulsifying activity. Emulsifying activity was evaluated according to the procedure described by Pearce and Kinsella ${ }^{7)}$ with slight modification. An emulsion was prepared by homogenizing a $2 \%(\mathrm{w} / \mathrm{w})$ peptide solution and $20 \%$ (w/w) soybean oil (Sanko Pharmaceutical Co., Japan) at $30^{\circ} \mathrm{C}$ with a Polytron PTA-7 (Kinematica, Switzerland) for $3 \mathrm{~min}$ at full speed $(19,500 \mathrm{rpm})$. The emulsion was immediately diluted with $0.1 \%$ SDS and its turbidity was measured at $500 \mathrm{~nm}$. Emulsifying activity is presented in terms of the emulsifying activity index (EAI).

Solubility. The solubilities of peptides were measured at $\mathrm{pH} 3 \sim 10$. Peptide solutions of $2 \%$ concentration $(w / v)$ in $0.1 \mathrm{M} \mathrm{NaCl}$ were centrifuged at $8,000 \times g$ for $30 \mathrm{~min}$. The peptide concentration of the supernatant was determined by the procedure of Lowry et al., the solubility being expressed as (peptide concentration of the supernatant/peptide concentration of the initial solution) $\times 100(\%)$.

Surface tension. The surface tension of the peptide (protein) solutions was monitored with a Wilhelmy platetype surface tensiometer (Kyowa CBVP type A-3) at $20^{\circ} \mathrm{C}$. The $\mathrm{pH}$ of each peptide solution $(0.05 \%, \mathrm{w} / \mathrm{v})$ was adjusted to 3 or 7 .

Electron microscopic observation. The electron microscopic observation was performed using a scanning electron microscope (SEM, HITACHI BH-2 RFK) equipped with a cryogenic system. An emulsion was mixed with two volumes of a $2 \%$ agar solution at $45 \sim 50^{\circ} \mathrm{C}$ and allowed to stand for $15 \sim 30 \mathrm{~min}$. The gel was sliced to a $1 \sim 2 \mathrm{~mm}$ thickness and soaked in $50 \%$ ethanol for $15 \mathrm{~min}$. The ethanol-treated gel slice was set in the sample chamber of the microscope and frozen by liquid nitrogen for $20 \mathrm{sec}$. The sample was then cleaved by a cold knife edge and allowed to etch for an appropriate time. The surface of the sample was finally coated with platinum-palladium and examined with a Hitachi S-800 scanning electron microscope.

\section{RESULTS}

\section{Isolation of the peptides}

The $\beta$-CN (f193 209) fraction was obtained from the chymosin hydrolyzate of $\beta$ casein. The yield was about $40 \mathrm{mg} / \mathrm{g}$ of $\beta$ casein. The peptide fraction showed no band on slab-polyacrylamide gel electrophoresis (PAGE, data not shown), but produced one peak by HPLC analysis on an ODS-column as shown in Fig. 1. The eluate corresponding to the peak was collected and its amino acid composition was analyzed. The amino acid comosition of this fraction (Table I) indicates that this peptide corresponded to the $\mathrm{C}$ terminal 193 209 residues of $\beta$-casein.

The $\beta$-CN (f1 25) fraction was obtained from the trypsin hydrolyzate of $\beta$-casein. The peptide fraction showed no band on slabPAGE (data not shown). The HPLC pattern of this fraction on an ODS-column is shown in Fig. 2. Only one peak was observed, indicating the high purity of this fraction. The amino acid analysis of the eluate corresponding to the

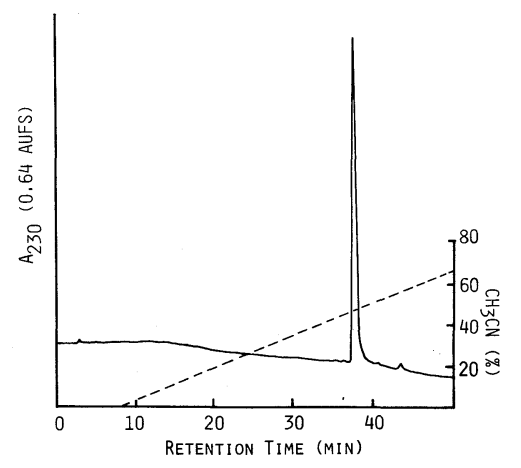

FIG. 1. HPLC of the $\beta$-CN (f193 209) Peptide Fraction on a Lichrosorb RP-18 Column $(\phi 4.0 \times 250 \mathrm{~mm})$.

Primary solvent, $0.1 \%$ trifluoroacetic acid; secondary solvent, acetonitrile. The gradient profile is shown by the dotted line. 
Table I. Amino Acid Composition of the Peptides Obtained from Hydrolyzates of $\beta$-CASEIN

\begin{tabular}{|c|c|c|c|c|}
\hline \multirow{2}{*}{$\begin{array}{l}\text { Amino } \\
\text { acid }\end{array}$} & \multicolumn{2}{|c|}{$\beta$-CN (f193 209) } & \multicolumn{2}{|c|}{$\beta-\mathrm{CN}(\mathrm{f} 1 \sim 25)$} \\
\hline & $\begin{array}{c}\text { Molar } \\
\text { ratio }\end{array}$ & $\begin{array}{l}\text { Nearest }^{a} \\
\text { integer }\end{array}$ & $\begin{array}{l}\text { Molar } \\
\text { ratio }\end{array}$ & $\begin{array}{c}\text { Nearest }^{a} \\
\text { integer }\end{array}$ \\
\hline Asx & 0.20 & - & 1.21 & $1(1)$ \\
\hline Thr & 0.10 & - & 1.03 & $1(1)$ \\
\hline Ser & 0.26 & - & 4.02 & $4(5)$ \\
\hline Glx & 2.49 & $2(2)$ & 7.01 & $7(7)$ \\
\hline Pro & 4.42 & $4(4)$ & 1.22 & $1(1)$ \\
\hline Gly & 2.24 & $2(2)$ & 1.16 & $1(1)$ \\
\hline Ala & 0.07 & - & - & - \\
\hline Cys & 0.11 & - & - & - \\
\hline Val & 3.23 & $3(3)$ & 1.92 & $2(2)$ \\
\hline Met & - & - & - & - \\
\hline Ile & 1.59 & $2(2)$ & 1.78 & $2(2)$ \\
\hline Leu & 1.15 & $1(1)$ & 3.23 & $3(3)$ \\
\hline Tyr & 1.00 & $1(1)$ & - & - \\
\hline Phe & 0.98 & $1(1)$ & - & - \\
\hline Lys & 0.20 & - & - & - \\
\hline His & 0.06 & - & - & - \\
\hline Arg & 1.00 & $1(1)$ & 2.12 & $2(2)$ \\
\hline $\begin{array}{l}\text { Total } \\
\text { residue }\end{array}$ & & $17(17)$ & & $24(25)$ \\
\hline
\end{tabular}

a Theoretical values are shown in parentheses.

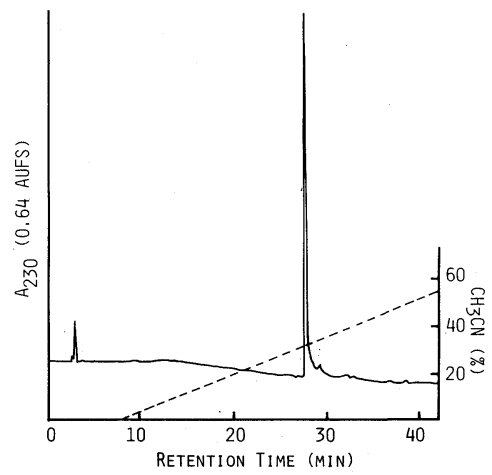

FIG. 2. HPLC of the $\beta$-CN (f1 25) Peptide Fraction on a LiChrosorb RP-18 Column.

The conditions are the same as in Fig. 1.

peak (Table I) indicates that this fraction corresponded to the $\mathrm{N}$-terminal $1 \sim 25$ residues of $\beta$-casein. The low values of Ser are considered to be due to its partial degradation during $\mathrm{HCl}$ hydrolysis as described by Peterson et al. ${ }^{6)}$ The yield of $\beta-\mathrm{CN}(\mathrm{fl} \sim 25)$ was about $70 \mathrm{mg} / \mathrm{g}$ of $\beta$-casein.
Table II. Emulsifying Activity and Structural Properties of the Peptides

\begin{tabular}{lccc}
\hline & $\begin{array}{c}\text { EAI } \\
\left(\mathrm{m}^{2} / \mathrm{g}\right)\end{array}$ & $\begin{array}{c}\text { Average } \\
\text { hydrophobicity }\end{array}$ & $\begin{array}{c}\text { Molecular } \\
\text { weight }\end{array}$ \\
\hline $\begin{array}{c}\beta-\mathrm{CN} \\
(\mathrm{f} 193 \sim 209)\end{array}$ & $8.2 \pm 0.8$ & 1,768 & 1,880 \\
$\beta-\mathrm{CN}$ & $10.4 \pm 0.6$ & 938 & 3,115 \\
$(\mathrm{f} 1 \sim 25)$ & & 1,170 & 23,614 \\
$\alpha_{\mathrm{s} 1}$-casein & $21.1 \pm 0.2$ & & \\
\hline
\end{tabular}

a Average hydrophobicity (HI) was calculated according to the method of Bigelow. ${ }^{9)}$

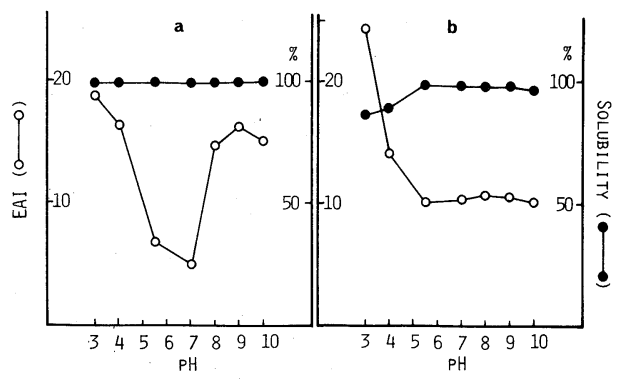

Fig. 3. Effect of $\mathrm{pH}$ on the Emulsifying Activity and Solubility of the Peptides.

a) $\beta$ - $\mathrm{CN}$ (f193 209); b) $\beta$-CN (f1 25). Emulsifying activity is expressed as the emulsifying activity index (EAI).

Table III. Surface Tension ${ }^{b}$ of The Peptides

\begin{tabular}{ccc} 
& $\beta$-CN $(\mathrm{f} 193 \sim 209)^{a}$ & $\beta-\mathrm{CH}(\mathrm{f1} \sim 25)^{a}$ \\
\hline pH 7 & 54.4 & 56.1 \\
pH 3 & 50.1 & 51.8 \\
\hline
\end{tabular}

a Peptide concentration, $0.05 \%(\mathrm{w} / \mathrm{v})$.

b. Surface tension (equilibrium).

\section{Emulsifying properties of the peptides}

The emulsifying activity index (EAI) of the two peptides was determined by comparing with that of $\alpha_{s 1}$-casein, and are shown in Table II. The average hydrophobicity of the peptides calculated by the procedure of Bigelow ${ }^{9)}$ is also shown in Table II. The $\beta$-CN (f1 25) peptide was hydrophilic, whereas the $\beta$-CN (f193 $209)$ peptide was very hydrophobic.

The EAI of $\beta$-CN (f1 25) was low when a $2 \%$ peptide solution (at $\mathrm{pH} 7$ ) was used for measurement. The hydrophobic peptide, $\beta$-CN 
(f193 209) also showed a remarkably low EAI.

\section{Effect of $\mathrm{pH}$ on the emulsifying activity}

The emulsifying activity and solubility of the two peptides at various $\mathrm{pH}$ values are shown in Fig. 3. Both peptides were soluble over the range of $\mathrm{pH}$ from 3 to 10 .

The EAI of $\beta$-CN (f193 209) was very low at $\mathrm{pH} 5.5 \sim 7$, but it showed high EAI values at less than $\mathrm{pH} 4$ and more than $\mathrm{pH}$ 8. On the other hand, $\beta$-CN (f1 25) showed a high value only at less than $\mathrm{pH} 4$.

\section{Surface tension}

The surface tension of the two peptide solutions after reaching equilibrium $(3 \sim 5 \mathrm{hr}$ after the initial measurement) was measured at $\mathrm{pH} 7$ and 3. The peptides seemed to be slightly more surface active at $\mathrm{pH} 3$ than at $\mathrm{pH} 7$

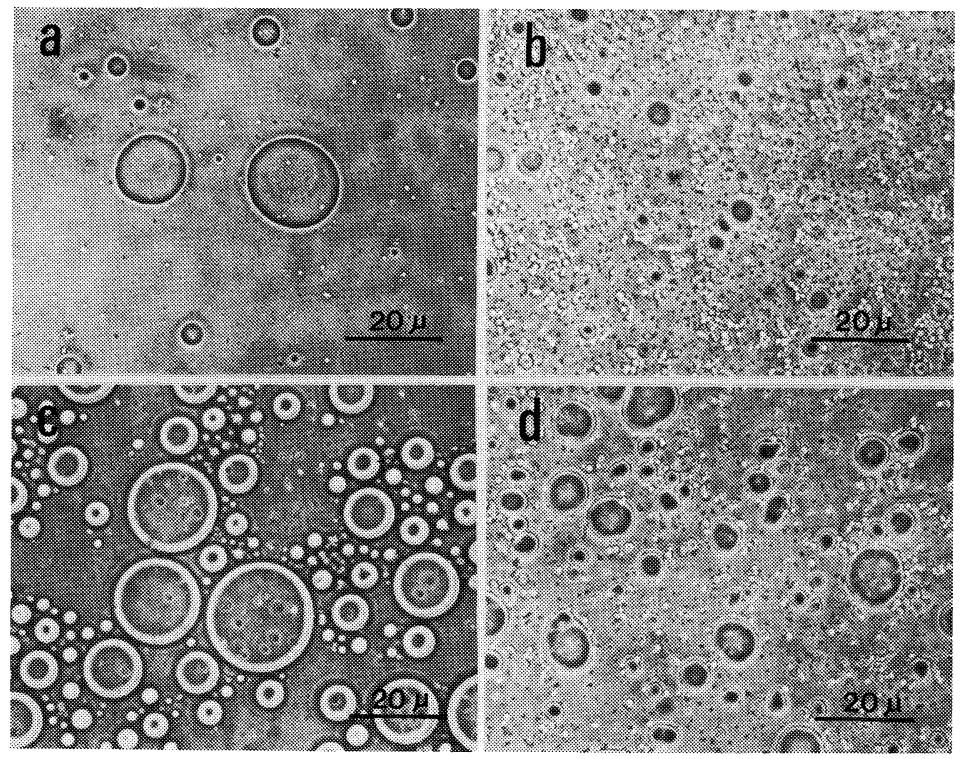

FIG. 4. Phase Contrast Microscopic Observations of Emulsions Prepared with the Peptides.

a) $\beta$-CN (f193 209), pH 7; b) $\beta$-CN (f193 209), pH 3; c) $\beta$-CN (f1 25), pH 7; d) $\beta$-CN (f1 25), pH 3.

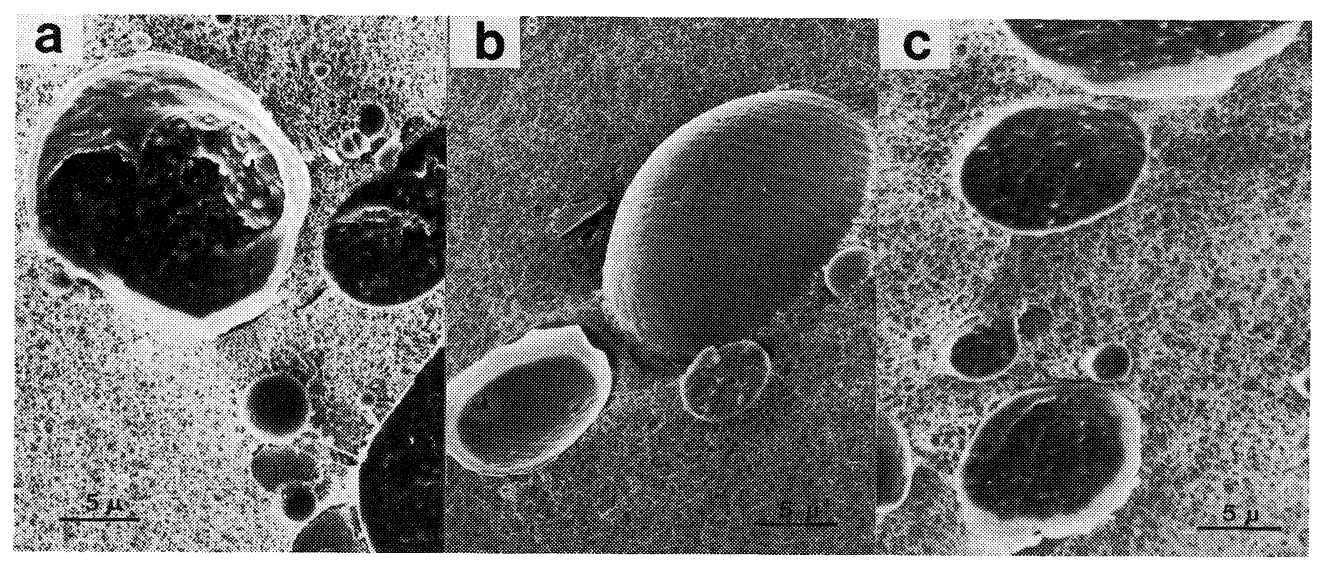

Fig. 5. Scanning Electron Micrographs of Emulsions Prepared with the Peptides.

a) $\beta$ - $\mathrm{CN}$ (f193 209), $\mathrm{pH} 3$; b) $\beta$ - $\mathrm{CN}$ (f1 25), pH 7; c) $\beta$-CN (f1 25), $\mathrm{pH} 3$. 
(Table III).

\section{Microscopic observation}

Emulsions prepared at $\mathrm{pH} 7$ and 3 were observed by phase contrast and scanning electron microscopy. $\beta$-CN (f193 209) did not produce a stable emulsion at $\mathrm{pH} 7$ (Fig. 4a), while a stable, fine dispersion of the oil droplets was observed at $\mathrm{pH} 3$ (Fig. 4b), in good agreement with Fig. 3a. The phosphopeptide was observed to form a stable emulsion at $\mathrm{pH}$ 7 , although the oil droplet size was relatively large (Fig. 4c). The droplet size of $\beta-\mathrm{CN}$ (f1 25) decreased at $\mathrm{pH} 3$ (Fig. 4d) in agreement with Fig. 3b. The scanning electron microscopy demonstrated that the oil droplets in the emulsions were covered with envelopes (Fig. 5), these envelopes being considered to be adsorbing layers of the peptides. Stabilization of the oil droplets could be achieved by these peptide films.

\section{DISCUSSION}

Many reports concerning the emulsifying properties of proteins have been published. However, the mechanism of emulsification by proteins remains obscure. This is mainly because of the highly complex structure of proteins and their dynamic properties at the oil/water interface during emulsification.

Peptides have simpler structure compared with proteins. Peptides of low molecular weight are considered to have fewer tertiary structures and a less rigid conformation. The contribution of the primary structure to the emulsifying property could be more pronounced in peptides. $\beta-\mathrm{CN}$ (f193 209) is a highly hydrophobic peptide containing only one ionic amino acid residue, while $\beta$ -
CN (f1 25) is highly hydrophilic, being rich in acidic amino acid residues. A marked difference in the emulsifying properties of these two peptides was therefore expected.

The present study, however, demonstrates that both peptides had very low emulsifying activity at a neutral $\mathrm{pH}$. In the previous paper, ${ }^{2)}$ we observed that an amphipathic peptide corresponding to the $\mathrm{N}$-terminal 23 residues of $\alpha_{\mathrm{s} 1}$-casein also showed a low EAI, although this peptide portion plays an important role in the interaction of $\alpha_{\mathrm{s} 1}$-casein with emulsified oil. ${ }^{10)}$ The fact that all of these peptides do not possess good emulsifying properties irrespective of the amino acid composition and hydrophobicity suggests that the chain length of the peptide seems to be a predominant factor for emulsification. Peptides of about 20 residues might be too short to have good emulsifying properties. Many authors have studied the functional properties of protein hydrolyzates, ${ }^{11 \sim 15}$ ) and postulated that the peptide chain length in the hydrolyzates should not be too small for achieving good emulsifying properties. The low emulsifying activities of the peptides used in this study may be due to the short chain length of these peptides.

In spite of the short chain length, the peptides showed high emulsifying activity when emulsification was carried out in the acidic or alkaline condition. It is well known that the $\mathrm{pH}$ change often influences the solubility of proteins, thereby affecting the emulsifying properties. However, the solubility of the two peptides used in this study did not change within the range of $\mathrm{pH} 3 \sim 10$, suggesing that the emulsifying properties of the peptides did not relate to the solubility.

$\beta$-CN (f193 209) showed high EAI values

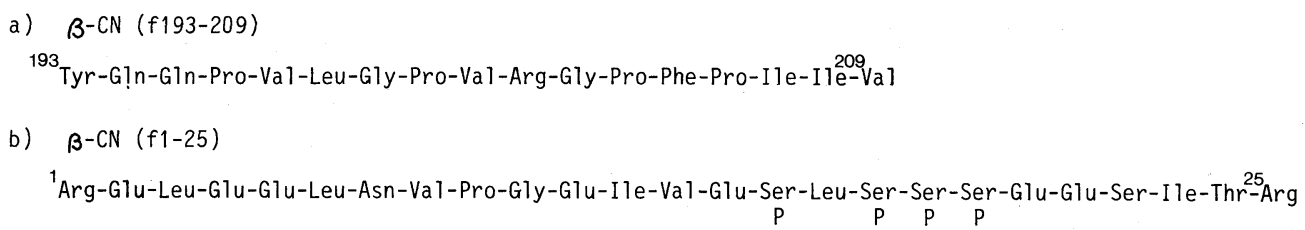

FIG. 6. Primary Structures of the Peptides. 
at above $\mathrm{pH} 8$ and below $\mathrm{pH} 4$. This result is unaccountable because $\beta$-CN (f193 209) is a peptide having only three ionizable amino acid residues, 193Tyr (N-terminal), 202 $\mathrm{Arg}$ and $209 \mathrm{Val}$ (C-terminal). Drastic changes to the structure of $\beta-\mathrm{CN}$ (f193 209) by changing $\mathrm{pH}$ seem to be unlikely within the $\mathrm{pH}$ range of $3 \sim 10$. However, the low surface tension of the peptide solution at $\mathrm{pH} 3$ (Table III) suggests that some structural change of the peptide occurred in the acidic $\mathrm{pH}$ region. $\beta-\mathrm{CN}$ (f1 25) also showed a high EAI and low surface tension at $\mathrm{pH}$ 3. Unlike $\beta$-CN (f193 209), the structure of $\beta-\mathrm{CN}$ (f1 25) is considered to be affected by changing $\mathrm{pH}$, since it contains $7 \mathrm{Glu}, 4$ phospho-Ser and 2 Arg residues. At $\mathrm{pH} 3$, dissociation of the Glu residues must be suppressed, which makes the $\mathrm{N}$-terminal portion of $\beta$-CN (f1 25) less hydrophilic. The amphipathic property of the $\beta$ $\mathrm{CN}$ (f1 25) molecule induced by such a change in the ionizable groups might have caused the increase in the emulsifying and surface activities. Secondary or tertiary (if any) structures of peptides and peptidepeptide association at the oil/water interface should be carefully considered as well to resolve the unaccountable properties of peptides for emulsification. In particular, peptide-peptide association must be important. The particularly thick adsorbing films observed by electron microscopy suggest that a high degree of association among the peptides might have occurred on the oil droplet surface. A more detailed investigation of this suggestion is necessary to elucidate the mechanism for emulsification by the peptide.

Acknowledgments. We are grateful to Mr. T. Kimura and Mr. Y. Sagara, of the Technical Research Institute of Snow Brand Milk Products Co., Ltd., for carrying out the microscopic .analyses.

\section{REFERENCES}

1) M. Shimizu, S. W. Lee, S. Kaminogawa and K. Yamauchi, J. Food Sci., 49, 1117 (1984).

2) M. Shimizu, S. W. Lee, S. Kaminogawa and K. Yamauchi, J. Food Sci., in press.

3) F. Glosclaude, M. F.-Mahe and B. RibadeauDumas, Eur. J. Biochem., 40, 323 (1973).

4) B. Ribadeau-Dumas, G. Brignon, F. Grosclaude and J.-C. Mercier, Eur. J. Biochem., 25, 505 (1972).

5) P. F. Fox and J. Guiney, J. Dairy Res., 39, 49 (1972).

6) R. F. Peterson, L. W. Nauman and T. L. McMeekin, J. Am. Chem. Soc., 80, 95 (1958).

7) K. N. Pearce and J. E. Kinsella, J. Agric. Food Chem., 26, 716 (1978).

8) O. H. Lowry, N. J. Rosebrough, A. L. Farr and R. J. Randall, J. Biol. Chem., 193, 265 (1951).

9) C. C. Bigelow, J. Theoret. Biol., 16, 187 (1967).

10) M. Shimizu, T. Takahashi, S. Kaminogawa and K. Yamauchi, J. Agric. Food Chem., 31, 1214 (1983).

11) C. A. Kuehler and C. M. Stine, J. Food Sci., 39, 379 (1974).

12) T. Horiuchi and D. Fukushima, Food Chem., 3, 35 (1978).

13) J. Adler-Nissen and H. S. Olsen, "Functionality and Protein Structure," American Chemical Society, Washington D. C., 1979, p. 125.

14) R. Jost and J. C. Monti, Lait, 62, 521 (1982).

15) E. H. Rahma and M. S. Narasinga, J. Agric. Food Chem., 31, 356 (1983). 